\title{
Growth and gas exchanges in soursop under irrigation with saline water and nitrogen sources
}

\author{
Evandro M. da Silva ${ }^{1}$, Geovani S. de Lima ${ }^{2}$, Hans R. Gheyi ${ }^{3}$, \\ Reginaldo G. Nobre ${ }^{4}$, Francisco V. da S. Sá ${ }^{5} \&$ Leandro de P. Souza ${ }^{1}$
}

\begin{abstract}
${ }^{1}$ Universidade Federal de Campina Grande/Centro de Tecnologia e Recursos Naturais/Programa de Pós-Graduação em Engenharia Agrícola. Campina Grande, PB. E-mail: evandroagroman@hotmail.com - ORCID: 0000-0001-9062-4738 (Corresponding author); engenheiropadua@hotmail.com- ORCID: 0000-0001-7588-2413

${ }^{2}$ Universidade Federal de Campina Grande/Centro de Ciências e Tecnologia Agroalimentar/Programa de Pós-Graduação em Horticultura Tropical. Pombal, PB. E-mail: geovanisoareslima@gmail.com - ORCID: 0000-0001-9960-1858

${ }^{3}$ Universidade Federal do Recôncavo da Bahia/Núcleo de Engenharia de Água e Solo. Cruz das Almas, BA. E-mail: hans@pq.cnpq.br - ORCID: 00000002-1066-0315

${ }^{4}$ Universidade Federal Rural do Semi-Árido/Departamento de Ciências e Tecnologia. Caraúbas, RN - E-mail: rgomesnobre@yahoo.com.br - ORCID: 0000-0002-6429-1527

${ }^{5}$ Universidade Federal Rural do Semi-Árido/Centro de Ciências Agrárias/Programa de Pós-Graduação em Manejo de Solo e Água. Mossoró, RN. E-mail: vanies_agronomia@hotmail.com - ORCID: 0000-0001-6585-8161
\end{abstract}

\section{Key words: \\ Annona muricata L. \\ salinity \\ nitrogen \\ photosynthesis}

\begin{abstract}
A B S T R A C T
Nitrogen $(\mathrm{N})$ fertilization has been tested for the mitigation of salt stress in some species including fruit crops. However, special attention should be paid to the source of $\mathrm{N}$, due to the different compositions and saline indices of the fertilizers, particularly when irrigation is conducted using waters with salinity levels that are restrictive to agriculture. Thus, this study evaluated the effect of fertilization with $\mathrm{N}$ sources on the growth and gas exchanges of soursop irrigated with saline water after transplanting. The experiment was carried out in greenhouse at the Center of Technology and Natural Resources of the Federal University of Campina Grande, and treatments were arranged in randomized blocks, in 4 x 4 factorial scheme, corresponding to electrical conductivity of water $-0.5,1.1,2.5$ and $3.5 \mathrm{dS} \mathrm{m}^{-1}$, and the $\mathrm{N}$ sources urea, ammonia sulfate, calcium nitrate and potassium nitrate, with three replicates. Growth and gas exchanges of soursop at 110 days after transplanting were not influenced by either the interaction between water salinity and $\mathrm{N}$ sources or the individual action of $\mathrm{N}$, but were inhibited by the increase in water salinity from $0.5 \mathrm{dS} \mathrm{m}^{-1}$. Increasing water salinity inhibited stomatal opening and carboxylation in the leaves.
\end{abstract}

\section{Palavras-chave:}

Annona muricata L. salinidade nitrogênio fotossíntese

\section{Crescimento e trocas gasosas em gravioleira sob irrigação com águas salinas e fontes de nitrogênio}

\section{R E S U M O}

A adubação nitrogenada vem sendo testada na mitigação do estresse salino, em algumas espécies inclusive em frutíferas; todavia, atenção especial deve ser dada à fonte de $\mathrm{N}$ devido às diferentes composições e os índices salinos dos fertilizantes, principalmente quando se irriga com águas de salinidade restritiva à agricultura. Neste sentido, estudou-se o efeito da adubação com fontes de nitrogênio sobre o crescimento e trocas gasosas de gravioleira irrigada com águas salinas após o transplantio. O experimento foi desenvolvido em casa de vegetação do Centro de Tecnologia e Recursos Naturais da Universidade Federal de Campina Grande, com os tratamentos distribuídos em blocos casualizados, em esquema fatorial $4 \times 4$, correspondente aos níveis de condutividade elétrica da água de 0,$5 ; 1,1 ; 2,5$ e 3,5 dS m$~ m^{-1}$ e as fontes de nitrogênio: ureia, sulfato de amônia, nitrato de cálcio e nitrato de potássio, com três repetições. O crescimento e as trocas gasosas da gravioleira aos 110 dias após o transplantio não foram influenciados pela interação entre a salinidade da água e as fontes de nitrogênio e nem pela ação isolada de $\mathrm{N}$, mas foram inibidos pelo aumento da salinidade da água a partir de $0,5 \mathrm{dS} \mathrm{m} \mathrm{m}^{-1}$. O aumento da salinidade da água inibiu a abertura estomática e a carboxilação no interior das folhas. 


\section{INTRODUCTION}

Soursop is a tropical fruit crop with prospects of production and marketing in almost all the Brazilian territory, especially in the Northeastern semi-arid region, where the edaphoclimatic conditions are favorable to its exploitation (Silva et al., 2013).

Nevertheless, in this region the cationic composition of the water used in irrigated plantations is the greatest limitation for the establishment of this fruit crop (Cavalcante et al., 2001), which undergoes reduction in growth and phytomass accumulation when irrigated using water with salinity from $1.5 \mathrm{dS} \mathrm{m}^{-1}$ (Nobre et al., 2003).

One of the serious problems of water salinity for plants is the loss of photosynthetic activity, attributed to stomatal and non-stomatal limitations (Cha-um \& Kirdmanee, 2011; Freire et al., 2014; Sousa et al., 2016), which negatively affect crop growth and yield (Kusvuran, 2012). This situation justifies the conduction of research in an attempt to reduce the deleterious effects of salts on the plants.

Alternatives have been tested to mitigate the effects of salinity on plants, for instance, $\mathrm{N}$ fertilization in the guava crop using urea as N source (Silva et al., 2017). There are also studies about the attenuating action of calcium nitrate and potassium nitrate on the salt stress on the melon crop (Fernandes et al., 2010; Andrade Júnior et al., 2011).

For Campos et al. (2010), the positive action of $\mathrm{N}$ on the reduction of deleterious effects varies with the form of $\mathrm{N}$ applied (nitric or ammoniacal) and plant species. Despite the promising data related to the action of $\mathrm{N}$ on the reduction of the severe effects of salts on plants, studies on the most adequate source of $\mathrm{N}$ for the soursop crop subjected to water salinity are still incipient in the literature.

Given the above, this study aimed to evaluate the effect of fertilization with $\mathrm{N}$ sources on the growth and gas exchanges of soursop, after transplantation, irrigated with saline water.

\section{MAterial ANd Methods}

The experiment was carried out in a greenhouse at the Center of Technology and Natural Resources (CTRN) of the Federal University of Campina Grande (UFCG), at the local geographic coordinates $7^{\circ} 12^{\prime} 88^{\prime \prime}$ South, 35 54' 40" West, at mean altitude of $532 \mathrm{~m}$.

Treatments were arranged in $4 \times 4$ factorial scheme, corresponding to four levels of irrigation water salinity - ECw:
$0.5,1.5,2.5$ and $3.5 \mathrm{dS} \mathrm{m}^{-1}$, and four $\mathrm{N}$ sources: urea, ammonia sulfate - AS; calcium nitrate - $\mathrm{CN}$ and potassium nitrate $\mathrm{KN}$, distributed in randomized blocks, with three replicates. Each plot consisted of one pot with one plant, totaling 48 experimental units.

Irrigation with saline water began at 10 days after transplanting (DAT). Water consumption by the crop was determined based on the drainage lysimetry principle (Bernardo et al., 2006). At 60 DAT, a leaching fraction of 0.15 was applied in all treatments based on the volume applied in this period, to minimize the accumulation of salts in the soil.

Saline waters with electrical conductivity of 0.5 and $1.5 \mathrm{dS} \mathrm{m}^{-1}$ were prepared by mixing rainwater $\left(\mathrm{EC}=0.02 \mathrm{dS} \mathrm{m}^{-1}\right)$ in water from the local supply system $\left(1.7 \mathrm{dS} \mathrm{m}^{-1}\right)$, whereas those with EC of 2.5 and $3.5 \mathrm{dS} \mathrm{m}^{-1}$ were prepared by the addition of adequate quantities of commercial iodate-free $\mathrm{NaCl}$ salts.

The $\mathrm{N}$ dose applied through urea, ammonium sulfate, calcium nitrate and potassium nitrate, whose saline indices are 75, 69, 61 and 74\%, respectively (Borges \& Silva, 2011), as well as the phosphate and potassium fertilizations, were applied according to the recommendations for pot experiments (Novais et al., 1991), using 100, 300 and $150 \mathrm{mg} \mathrm{kg}^{-1}$ of soil of $\mathrm{N}_{2} \mathrm{P}_{2} \mathrm{O}_{5}$ and $\mathrm{K}_{2} \mathrm{O}$, respectively. Phosphate fertilization was performed by incorporating single superphosphate to the soil, whereas nitrogen and potassium fertilizations (potassium chloride) were split into six equal portions, and each fertilizer was diluted in $150 \mathrm{~mL}$ of rainwater with EC of $0.02 \mathrm{dS} \mathrm{m}^{-1}$. Fertilizations with $\mathrm{N}$ and $\mathrm{K}$ began at $20 \mathrm{DAT}$, followed by applications every 10 days.

The soursop variety 'Nordestina' was used and its seedlings were obtained by sowing in plastic tubes with volumetric capacity of $288 \mathrm{~cm}^{3}$, containing substrate composed of soil and humus at 2:1 proportion, respectively. Transplantation was carried out at 86 days after sowing, when the seedlings had four true leaves (fully expanded), to pots with capacity for $22 \mathrm{dm}^{3}$, containing $20 \mathrm{~kg}$ of soil. Its physical and chemical characteristics (Table 1) were determined according to the methodologies recommended by Donagema et al. (2011).

The planting pots contained $0.5 \mathrm{~kg}$ of crushed stone at the base, forming a 1-cm-thick layer involved by a nonwoven geotextile (Bidim OP 30), connected to a drain attached to a hose (20 mm diameter), which was used to monitor the volume drained and estimate water consumption by the crop.

Effects of the treatments on plant growth were evaluated at 110 days after transplanting (DAT), based on plant height

Table 1. Physical and chemical attributes of the soil used in the experiment

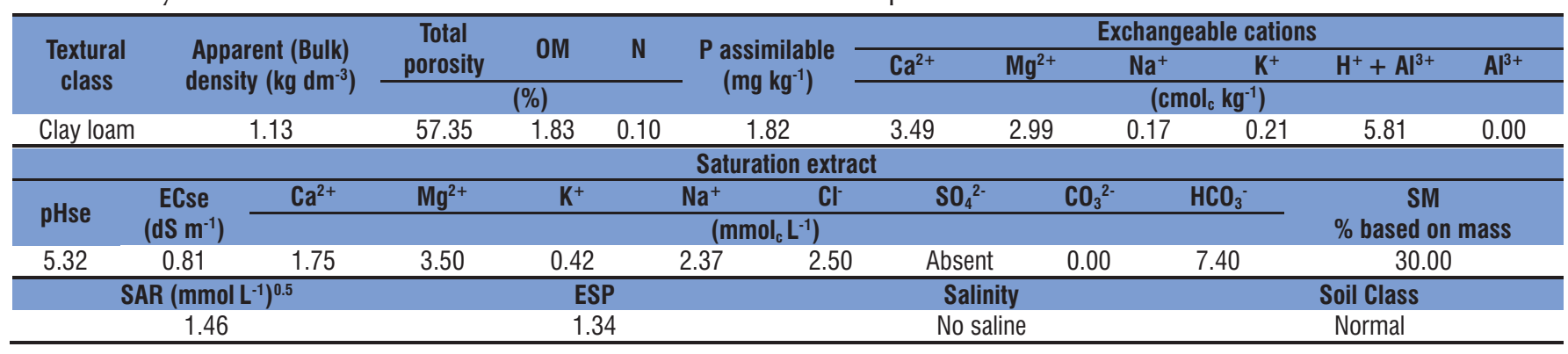

$\mathrm{OM}$ - Organic matter estimated by Walkley-Black wet digestion; $\mathrm{pHse}-\mathrm{pH}$ of the saturation extract, ECse - Electrical conductivity of the saturation extract at $25^{\circ} \mathrm{C}$; $\mathrm{SAR}-\mathrm{Sodium}$ adsorption ratio ESP - Exchangeable sodium percentage; $\mathrm{P}, \mathrm{K}$ and $\mathrm{Na}$ - Extracted by Mehlich $1 ; \mathrm{Ca}, \mathrm{Mg}$ - Extracted by $1.0 \mathrm{M} \mathrm{KCl} ; \mathrm{H}^{+}+\mathrm{Al}^{3+}$ - Extracted by $0.5 \mathrm{M} \mathrm{CaOAc}, \mathrm{SM}-\mathrm{Soil}$ moisture content at saturation 
$(\mathrm{PH})$, measured in the main stem from soil surface to the apical meristem; stem diameter (SD), measured at $5 \mathrm{~cm}$ height from the collar; number of leaves (NL), determined by counting the leaves with fully open lamina; and the values of stem dry matter (StDM), leaf dry matter (LDM), shoot dry matter (ShDM), root dry matter (RDM) and total dry matter (TDM), determined on precision scale $(0.001 \mathrm{~g})$, after drying the different plant organs in a forced-air oven at temperature $65^{\circ} \mathrm{C}$ for $72 \mathrm{~h}$.

In the same period (110 DAT), gas exchanges of soursop plants were measured in the middle leaf of the main stem: internal $\mathrm{CO}_{2}$ concentration $(\mathrm{Ci})$, stomatal conductance (gs), transpiration (E) and $\mathrm{CO}_{2}$ assimilation rate (A), using a portable infrared gas analyzer (IRGA) - LCPro+ Portable Photosynthesis System ${ }^{\circledR}$ (ADC BioScientific Limited, UK), operating at temperature adjusted to $25{ }^{\circ} \mathrm{C}$, irradiation of $1800 \mu \mathrm{mol}$ photons $\mathrm{m}^{-2} \mathrm{~s}^{-1}$ and air flux of $200 \mathrm{~mL} \mathrm{~min}^{-1}$, and atmospheric $\mathrm{CO}_{2}$ concentration.

The data were subjected to analysis of variance by $\mathrm{F}$ test, at 0.05 and 0.01 probability level, and to regression using the statistical program SISVAR/UFLA to process the data (Ferreira, 2011).

\section{Results AND Discussion}

Irrigation water salinity caused significant effect on all growth variables evaluated (Table 2). However, none of the variables responded to the effects of either the interaction between irrigation water salinity and $\mathrm{N}$ sources or the respective $\mathrm{N}$ sources individually. This situation is in accordance with Oliveira et al. (2010), who observed that the interaction between water salinity and $\mathrm{N}$ sources did not interfere significantly with the leaf growth and phytomass accumulation by sunflower (Helianthus annus L.).

The use of calcium nitrate and potassium nitrate can minimize the negative effect of salinity on plant growth, because it increases the availability of $\mathrm{Ca}^{2+}$ and $\mathrm{K}^{+}$to plants, inhibiting the absorption and accumulation of $\mathrm{Na}^{+}$by ionic competition (Fernandes et al., 2010; Andrade Júnior et al., 2011). However, such effect did not occur in soursop plants under application of these fertilizers, as it did not differ from plants fertilized with urea and ammonium sulfate. Probably, potassium fertilization performed using potassium chloride and the availability of $\mathrm{Ca}^{2+}$ prevailing in the soil neutralized the possible effect, leading to no difference between the applications of different $\mathrm{N}$ sources.

Another factor which can compromise plant growth in the use of different $\mathrm{N}$ sources is the saline index (Oliveira et al.,
2010). Nonetheless, in the present study this phenomenon did not occur, since calcium nitrate, ammonium sulfate, potassium nitrate and urea, whose saline indices are 61, 69, 74 and 75\% respectively, did not cause differences in plant growth, probably because the quantities of these fertilizers applied in the soil were not sufficient to increase salinity in the root zone.

The increase in irrigation water salinity linearly inhibited soursop growth, causing reductions in plant height, stem diameter and leaf production of $7.73,9.39$ and $8.72 \%$, respectively, per unit increase in irrigation water electrical conductivity (Figures 1A, B and C). There were also losses in the biomass production capacity by soursop, with reductions of $18.60,17.82,18.16,20.05$ and $18.81 \%$ per unit increase in irrigation water salinity, in the dry biomass of stem, leaves, shoots (stem and leaves), roots and total (roots, stems and leaves) (Figures 1D, E, F, G and H).

Growth inhibition in the plants under saline conditions occurs due to the osmotic and toxic effects of the salt and specific ions, especially $\mathrm{Na}^{+}$and $\mathrm{Cl}^{-}$, leading to losses in water absorption and reduction in $\mathrm{K}^{+} / \mathrm{Na}^{+}, \mathrm{Ca}^{2+} / \mathrm{Na}^{+}$and $\mathrm{NO}_{3}-\mathrm{Cl}^{-}$ratios in plant tissues, which hinders cell ion homeostasis (Apse \& Blumwald, 2007; Taiz et al., 2017).

Willadino \& Camara (2010) report that, under saline conditions, there are reductions in cell elongation and division, caused by the low turgor of cells, due to the reduction in water absorption by the plant, in response to the decrease in the osmotic potential induced by the salts in the water, soil and also in plants (Freire et al., 2014). This situation leads to increments in the $\mathrm{Na}^{+}$content in plant tissues, which interfere with the homeostasis of $\mathrm{K}^{+}$ions and reduce the availability, transport and mobilization of $\mathrm{Ca}^{2+}$ to the regions of growth, such as cell membranes and walls, whose permeability and elasticity are harmed, negatively affecting plant growth (Kaddour et al., 2012).

Besides the inconveniences discussed, plants tend to divert assimilates to osmotic adjustment, which could be used in the synthesis of proteins and cell wall, culminating in reductions of growth and phytomass accumulation in the plants (Taiz et al., 2017). It can also result from the low assimilation of carbon, caused by the reduction in $\mathrm{CO}_{2}$ diffusion to inside the leaf due to stomatal closure, which compromises the photosynthetic activity and consequently plant growth (Kusvuran, 2012; Freire et al., 2014; Sousa et al., 2016).

As observed for growth, the physiological variables of soursop, despite being influenced by irrigation water salinity (Table 3), did not respond to the effects of the interaction between water salinity and $\mathrm{N}$ sources.

Table 2. Summary of analysis of variance for plant height $(\mathrm{PH})$, stem diameter $(\mathrm{SD})$, number of leaves (NL), stem dry matter (StDM), leaf dry matter (LDM), shoot dry matter (ShDM), root dry matter (RDM) and total dry matter (TDM) of soursop plants, 'Nordestina' variety, irrigated with saline water and fertilized with different sources of nitrogen, at 110 days after transplanting

\begin{tabular}{|c|c|c|c|c|c|c|c|c|c|}
\hline \multirow{2}{*}{ Source of variation } & \multirow{2}{*}{ DF } & \multicolumn{8}{|c|}{ Mean square } \\
\hline & & $\mathrm{PH}$ & SD & $\overline{N L}$ & StDM & LDM & ShDM & RDM & TDM \\
\hline Salinity (S) & 3 & $294.880 * *$ & $8.878^{\star \star}$ & 119.138 ** & $6.0429 * *$ & $9.7798 * *$ & $31.1824^{\star \star}$ & 11.006 ** & $79.051^{\star *}$ \\
\hline Nitrogen sources (NS) & 3 & $46.302^{\text {ns }}$ & $0.518^{\mathrm{ns}}$ & $18.083^{\text {ns }}$ & $0.4477^{\mathrm{ns}}$ & $0.4003^{\text {ns }}$ & $1.6616^{\mathrm{ns}}$ & $0.1402^{\text {ns }}$ & $2.6116^{\mathrm{ns}}$ \\
\hline Interaction $S^{*} N S$ & 9 & $47.061^{\mathrm{ns}}$ & $0.502^{\text {ns }}$ & $6.102^{\mathrm{ns}}$ & $0.1758^{\text {ns }}$ & $0.2791^{\mathrm{ns}}$ & $0.8019^{\text {ns }}$ & $0.2707^{\mathrm{ns}}$ & $1.7774^{\mathrm{ns}}$ \\
\hline Blocks & 2 & 296.320 ** & $1.256^{\mathrm{ns}}$ & $8.271^{\text {ns }}$ & $0.8414^{\mathrm{ns}}$ & $1.4256^{\mathrm{ns}}$ & $4.4234^{\mathrm{ns}}$ & $1.5305^{\mathrm{ns}}$ & $9.6175^{\mathrm{ns}}$ \\
\hline Residue & 30 & 42.112 & 0.422 & 7.693 & 0.3553 & 0.6477 & 1.8911 & 0.8612 & 5.1316 \\
\hline CV (\%) & - & 15.64 & 11.40 & 12.04 & 32.92 & 32.37 & 32.00 & 43.01 & 35.09 \\
\hline
\end{tabular}

ns, ${ }^{* *}$ Not significant and significant at $p<0.01$, respectively; DF - Degrees of freedom; CV - Coefficient of variation 

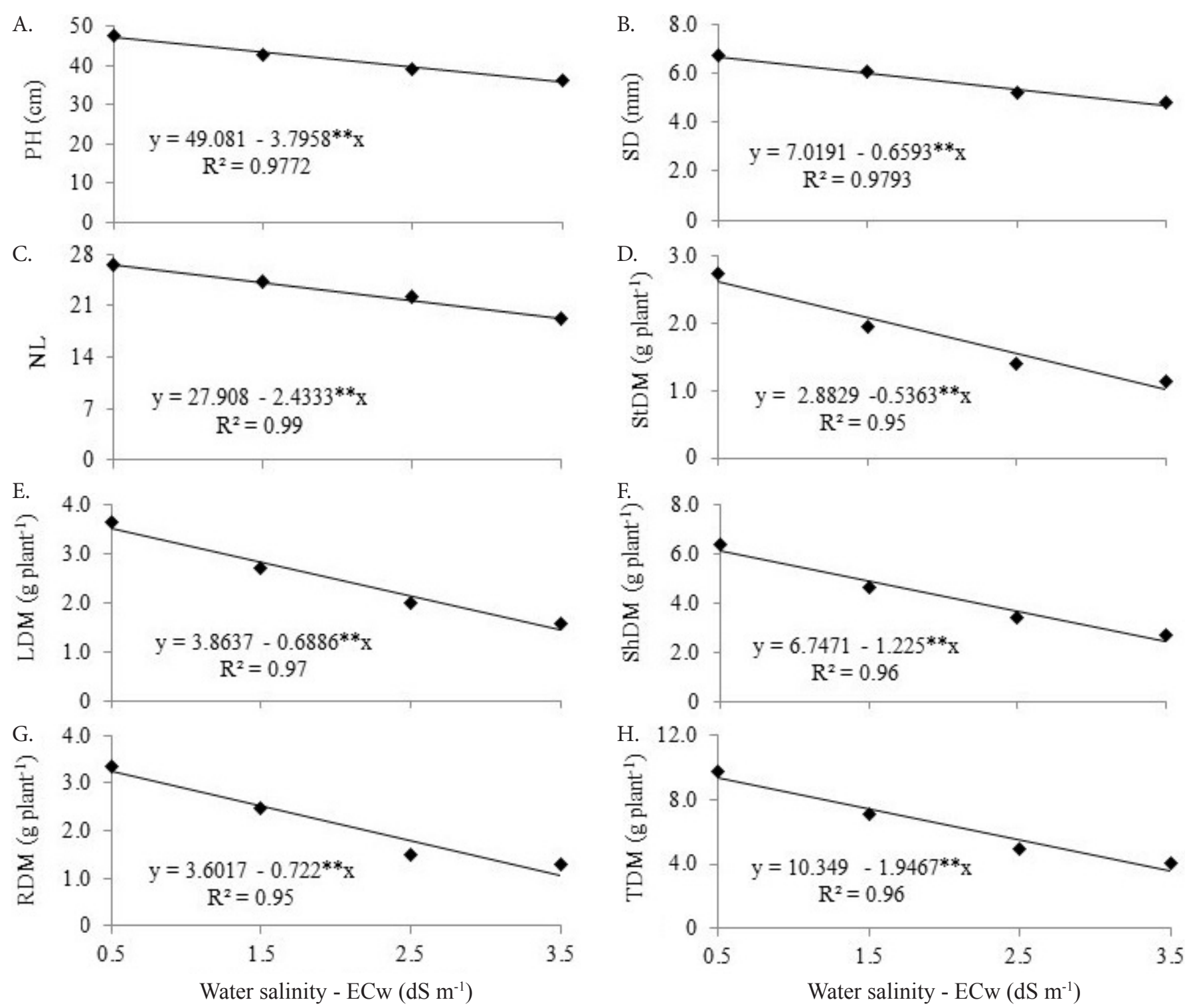

Figure 1. Plant height - PH (A), stem diameter - SD (B), number of leaves - NL (C), stem dry matter (StDM) (D), leaf dry matter - LDM (E), shoot dry matter - ShDM (F), root dry matter - RDM (G) and total dry matter - TDM (H) of soursop plants, 'Nordestina' variety, irrigated with saline water and fertilized with different sources of $\mathrm{N}$, at 110 days after transplanting

Table 3. Summary of analysis of variance for stomatal conductance $(\mathrm{gs})$, transpiration $(\mathrm{E}), \mathrm{CO}_{2}$ assimilation rate (A) and internal $\mathrm{CO}_{2}$ concentration $(\mathrm{Ci})$ in soursop plants, 'Nordestina' variety, irrigated with saline water and fertilized with different sources of nitrogen, at 110 days after transplanting

\begin{tabular}{|c|c|c|c|c|}
\hline \multirow{2}{*}{ Source of variation } & \multicolumn{4}{|c|}{ Mean Square } \\
\hline & gs & $E$ & $\bar{A}$ & $\overline{\mathrm{Ci}}$ \\
\hline Salinity (S) & $30.000941^{\star *}$ & $0.11436^{\star \star}$ & $19.0143^{\star \star}$ & $17676.50^{\star *}$ \\
\hline Nitrogen sources (NS) & $30.000097^{\text {ns }}$ & $0.0096^{\text {ns }}$ & $1.0328^{\mathrm{ns}}$ & $2886.50^{\text {ns }}$ \\
\hline Interaction S*NS & $90.000174^{\text {ns }}$ & $0.0222^{\mathrm{ns}}$ & $0.3220^{\text {ns }}$ & $1062.40^{\text {ns }}$ \\
\hline Blocks & $20.000915^{\star *}$ & $0.2161 * *$ & $0.2459^{\text {ns }}$ & $23191.52^{\star *}$ \\
\hline Residue & $30 \quad 0.000095$ & 0.0107 & 1.1000 & 1378.90 \\
\hline CV (\%) & 26.08 & 17.93 & 40.92 & 13.62 \\
\hline
\end{tabular}

${ }^{\text {ns }},{ }^{* *}$ Not significant and significant at $p<0.01$, respectively; DF - Degrees of freedom; CV - Coefficient of variation

The increase in water salinity negatively affected gas exchanges in soursop plants (Figures 2A, B and C), causing reductions of $12.32,11.09$ and $21.58 \%$ in stomatal conductance (gs), transpiration (E) and $\mathrm{CO}_{2}$ assimilation rate (A) per unit increase in ECW. These reductions may be caused by the osmotic effects of salinity in the root zone of the plants. The harmful action of salinity on gs (Figure 2A) is a common response of glycophytes to salt stress, as a way to minimize water losses and maintain high cell water potential (Kusvuran, 2012; Freire et al., 2014; Sousa et al., 2016), probably regulated by the occurrence of a chemical signaling between roots and shoots after perceiving the osmotic stress, which stimulates stomatal closure (Souza et al., 2011).

Reduction in transpiration (Figure 2B) may result from stomatal closure, as observed in Figure 2A, caused by osmotic stress due to the increase of salinity in the root zone, in order to reduce water losses by transpiration, as observed in citrus plants (Sousa et al., 2016). These mechanisms which control E and gs probably occur because of the reduction of water potential in the roots or due to the synthesis and transport of abscisic acid (ABA) to the leaves (Souza et al., 2011), possibly regulated by the expression of genes, such as the Salt-Related MYB1, which induces ABA production in response to salt stress (Wang et al., 2015).

Decreases in $\mathrm{CO}_{2}$ assimilation rate as a function of the increase in salinity (Figure 2C) are consistent with the results 

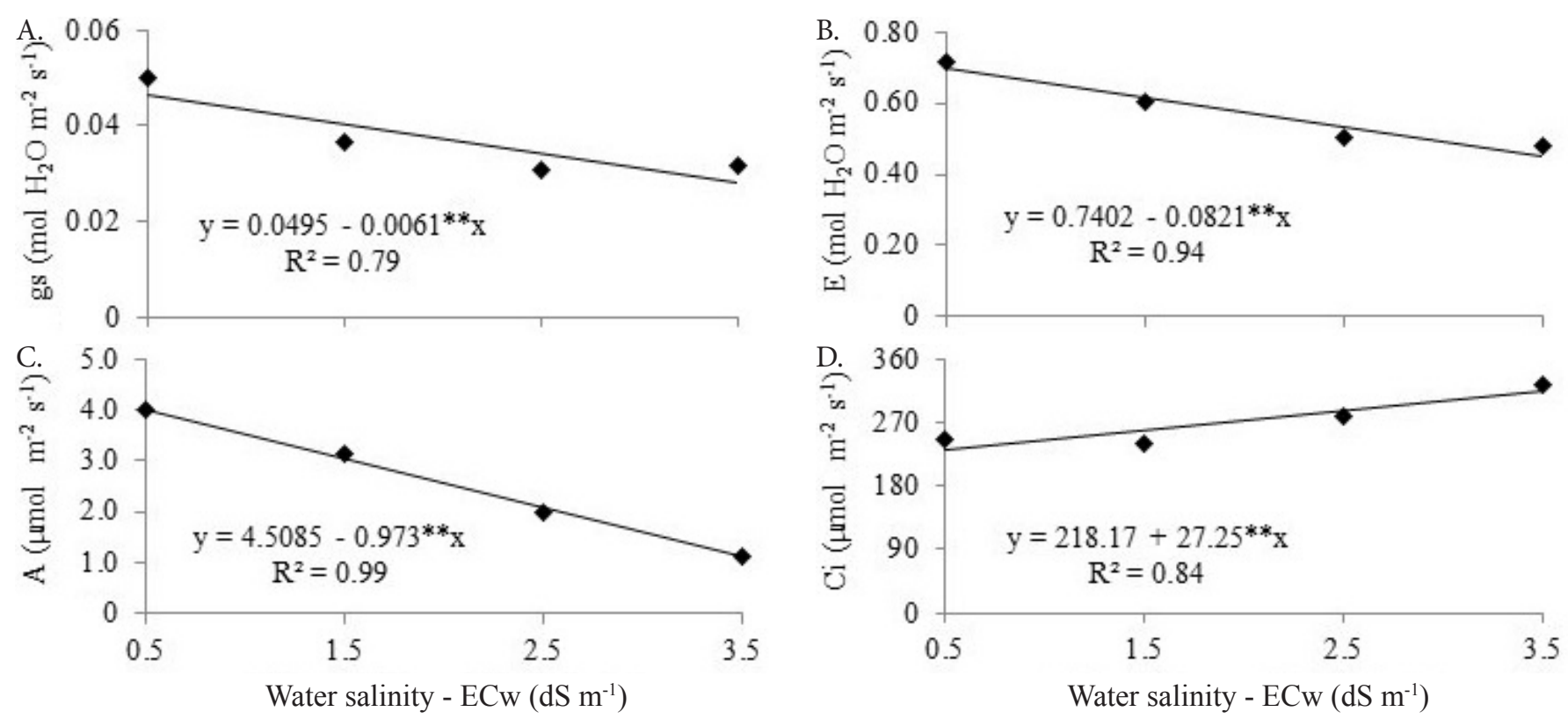

Figure 2. Stomatal conductance - gs (A), transpiration - E (B), $\mathrm{CO}_{2}$ assimilation rate $-\mathrm{A}(\mathrm{C})$ and internal $\mathrm{CO}_{2}$ concentration - Ci (D) in soursop plants, 'Nordestina' variety, irrigated with saline water at 110 days after transplanting

found by Freire et al. (2014) and Silva et al. (2014), respectively, in yellow passion fruit (Passiflora edulis Sims f. flavicarpa Degener) and citrus hybrids (trifoliate hybrids - 069, 116 and 127, 'Cravo' lemon and 'Common Sunki' mandarin C. sunki ).

According to these authors, reductions in leaf stomatal conductance due to salt stress limits $\mathrm{CO}_{2}$ entry in the cells because of the reduced stomatal opening, consequently leading to lower $\mathrm{CO}_{2}$ assimilation rate. Besides these alterations, low $\mathrm{CO}_{2}$ assimilation rates result in excess of light energy in photosystem II, which cause disorders in photochemical reactions and losses in photosynthesis and, consequently, in plant growth (Cha-um \& Kirdmanee, 2011; Freire et al., 2014), as observed in the present study.

Increments in water salinity levels caused linear increase of $12.49 \%$ in internal $\mathrm{CO}_{2}$ concentration per unit increase in ECw (Figure 2D). This situation reflects the negative effect of salinity on photosynthesis (Figure 2C), as also observed by Freire et al. (2014) in yellow passion fruit plants under salt stress.

Increment in $\mathrm{Ci}$ values is associated with $\mathrm{CO}_{2}$ accumulation in the leaves and probable reduction in the use of this gas for the synthesis of sugars (Taiz et al., 2017). Increases in water salinity can elevate $\mathrm{Cl}^{-}$concentration in the leaves, which causes a toxic effect, reducing the carboxylation efficiency of RuBisCO, the enzyme responsible for $\mathrm{C}$ fixation for the biochemical phase of photosynthesis, resulting in increase in internal $\mathrm{CO}_{2}$ concentration in the leaves (Souza et al., 2011).

According to the results, salinity negatively affects $\mathrm{CO}_{2}$ assimilation rate (net photosynthesis), in response to stomatal closure and low $\mathrm{CO}_{2}$ carboxylation in the substomatal chamber in the leaves. These variables are related to the growth of soursop plants, especially with respect to phytomass accumulation, because these variables and the $\mathrm{CO}_{2}$ assimilation rate are more harmed by the increase in salinity.

\section{Conclusions}

1. Growth and gas exchanges of soursop plants at 110 days after transplanting did not respond to either the interaction between water salinity and $\mathrm{N}$ sources or to the individual effect of these sources.

2. Water salinity from $0.5 \mathrm{dS} \mathrm{m}^{-1}$, regardless of the $\mathrm{N}$ source used, reduced the growth and gas exchanges, except the internal $\mathrm{CO}_{2}$ concentration.

3. Increasing water salinity inhibited stomatal opening and carboxylation in the substomatal chamber of the leaves.

\section{Literature Cited}

Andrade Júnior, W. P.; Pereira, F. H. F.; Fernandes, O. B.; Queiroga, R. C. F.; Queiroga, F. M. Efeito do nitrato de potássio na redução do estresse salino no meloeiro. Revista Caatinga, v.24, p.110119, 2011. https://periodicos.ufersa.edu.br/index.php/caatinga/ article/view/2280/4762

Apse, M. P.; Blumwald, E. Na ${ }^{+}$transport in plants. FEBS Letters, v.581, p.2247-2254, 2007. https://doi.org/10.1016/j.febslet.2007.04.014 Bernardo, S.; Soares, A. A.; Mantovani, E. C. Manual de irrigação. 8.ed. Viçosa: UFV, 2006. 625p.

Borges, A. L.; Silva, D. J. Fertilizantes para fertirrigação. In: Sousa, V. F.; Marouelli, W. A.; Coelho, E. F.; Maurício, J. M. P.; Coelho Filho, A. (eds.). Irrigação e fertirrigação em fruteiras e hortaliças. Brasília: Embrapa Informação Tecnológica, 2011. p.253-264.

Campos, M. S.; Oliveira, F. A.; Oliveira, F. R. A.; Silva, R. C. P.; Cândido, W. S. Efeito da salinidade e fontes de nitrogênio na matéria seca do girassol. Revista Verde de Agroecologia e Desenvolvimento Sustentável, v.5, p.165-171, 2010. http://www. gvaa.com.br/revista/index.php/RVADS/article/view/319/319

Cavalcante, L. F.; Carvalho, S. S.; Lima, E. M.; Feitosa Filho, J. C.; Silva, D. A. Desenvolvimento inicial da gravioleira sob fontes e níveis de salinidade da água. Revista Brasileira de Fruticultura, v.23, p.455459, 2001. https://doi.org/10.1590/S0100-29452001000200053

Cha-um, S.; Kirdmanee, C. Remediation of salt-affected soil by the addition of organic matter: An investigation into improving glutinous rice productivity. Scientia Agricola. v.68, p.406-410, 2011.http://dx.doi.org/10.1590/S0103-90162011000400003 
Donagema, G. K.; Campos D. V. B.; Calderano, S. B.; Teixeira, W. G.; Viana, J. H. M. Manual de métodos de análise de solo. Rio de Janeiro: Embrapa Solos, 2011. 230p.

Fernandes, O. B.; Pereira, F. H. F.; Andrade Júnior, W. P.; Queiroga, R. C. F.; Queiroga, F. M. Efeito do nitrato de cálcio na redução do estresse salino no meloeiro. Revista Caatinga, v.23, p.93103, 2010. https://periodicos.ufersa.edu.br/index.php/caatinga/ article/download/1766/4597

Ferreira, D. F. Sisvar: Um sistema computacional de análise estatística. Ciência e Agrotecnologia, v.35, p.1039-1042, 2011. http://dx.doi.org/10.1590/S1413-70542011000600001

Freire, J. L. O.; Dias, T. J.; Cavalcante, L. F.; Fernandes, P. D.; Lima Neto, A. J. Rendimento quântico e trocas gasosas em maracujazeiro amarelo sob salinidade hídrica, biofertilização e cobertura morta. Revista Ciência Agronômica, v.45, p.82-91, 2014. http://ccarevista.ufc.br/seer/index.php/ccarevista/article/ view/2420/906

Kaddour, R.; Mahmoudi, H.; Baâtour, O.; Tarchoun, I.; Nasri, N.; Saleh, I. B.; Berthomieu, P.; Gruber, M.; Lachaâl, M. Physiological and molecular responses of two arabidopsis accessions to calcium amendment and salt constraint. Acta Physiologia e Plantarum, v.34, p.439-450, 2012. http://dx.doi. org/10.1007/s11738-011-0840-7

Kusvuran, S. Effects of drought and salt stresses on growth, stomatal conductance, leaf water and osmotic potentials of melon genotypes (Cucumis melo L.). African Journal Agricultural Research, v.7, p.775-781, 2012. http://dx.doi.org/10.5897/ AJAR11.1783

Nobre, R. G.; Fernandes, P. D.; Gheyi, H. R.; Santos, F. J. S.; Bezerra, I. L.; Gurgel, M. T. Germinação e formação de mudas enxertadas de gravioleira sob estresse salino. Pesquisa Agropecuária Brasileira, v.38, p.1365-1371, 2003. https://doi.org/10.1590/ S0100-204X2003001200002

Novais, R. F.; Neves J. C. L.; Barros, N. F. Ensaio em ambiente controlado. In: Oliveira, A. J. (ed.). Métodos de pesquisa em fertilidade do solo. Brasília: Embrapa Informação Tecnológica, 1991. p.189-253.
Oliveira, F. A.; Oliveira, F. R. A.; Campos, M. S.; Oliveira, M. K. T.; Medeiros, J. F.; Silva, O. M. P. Interação entre salinidade e fontes de nitrogênio no desenvolvimento inicial da cultura do girassol. Revista Brasileira de Ciências Agrárias, v.5, p.479-484, 2010. https://doi.org/10.5039/agraria.v5i4a806

Silva, E. M.; Nobre, R. G.; Souza, L. P.; Pinheiro, F. W. A.; Lima, G. S.; Gheyi, H. R.; Almeida, L. L. S. Physiology of 'Paluma' guava under irrigation with saline water and nitrogen fertilization. Semina: Ciências Agrárias, v.38, p.623-634, 2017. http://dx.doi. org/10.5433/1679-0359.2017v38n2p623

Silva, L. A.; Brito, M. E. B.; Sá, F. V. S.; Moreira, R. C. L.; Soares Filho, W. S.; Fernandes, P. D. Mecanismos fisiológicos em híbridos de citros sob estresse salino em cultivo hidropônico. Revista Brasileira de Engenharia Agrícola e Ambiental, v.18, p.S1-S7, 2014. http:// dx.doi.org/10.1590/1807-1929/agriambi.v18nsupps1-s7

Silva, R. A. R.; Nunes, J. C.; Lima Neto, A. J.; Cavalcante, L. F.; Silva, M. R. M. da; Rodrigues, R. M. Lâminas de irrigação e cobertura do solo na produção e qualidade de frutos da gravioleira. Revista Brasileira de Ciências Agrárias, v.8, p.441-447, 2013. http:// dx.doi.org/10.5039/agraria.v8i3a2669

Sousa, J. R. M.; Gheyi, H. R.; Brito, M. E. B.; Xavier, D. A.; Furtado, G. F. Impact of saline conditions and nitrogen fertilization on citrus production and gas exchanges. Revista Caatinga, v.29, p.415424, 2016. http://dx.doi.org/10.1590/1983-21252016v29n218rc

Souza, R. P.; Machado, E. C.; Silveira, J. A. G.; Ribeiro, R. V. Fotossíntese e acúmulo de solutos em feijoeiro caupi submetido à salinidade. Pesquisa Agropecuária Brasileira, v.46, p.586-592, 2011. https://doi.org/10.1590/S0100-204X2011000600003

Taiz, L.; Zeiger, E.; Møller, I. M.; Murphy, A. Fisiologia e desenvolvimento vegetal. 6.ed. Porto Alegre: Artmed, 2017. 858p.

Wang, T.; Tohge, T.; Ivakov, A.; Mueller-Roeber, B.; Fernie, A. R.; Mutwil, M.; Schippers, J. H. M.; Persson, S. Salt-related MYB1 coordinates abscisic acid biosynthesis and signaling during salt stress in Arabidopsis. Plant Physiology, v.169, p.1027-1041, 2015. https://doi.org/10.1104/pp.15.00962

Willadino, L.; Camara, T. R. Tolerância das plantas à salinidade: Aspectos fisiológicos e bioquímicos. Enciclopédia Biosfera, v.6, p.1-23, 2010. 